\title{
A Review of Color Matching in Dentistry
}

\section{Diş Hekimliğinde Renk Seçimi Derlemesi}

\author{
(1)Moataz Makhloota', @Aysegul Koroglu', @Bilge Turhan Bal' \\ 'Department of Prosthodontics,Zonguldak Bulent Ecevit University, Faculty of Dentistry, Zonguldak, Turkey \\ ${ }^{2}$ Department of Prosthodontics, Gazi University, Faculty of Dentistry, Ankara, Turkey \\ Copyright ( $\odot 2019$ by authors and Medical Records Publishing Inc.
}

\begin{abstract}
The success of dental treatment is evaluated according to functional and esthetic results. The esthetics of prostheses considered one of the most important parameters of treatment that the patient is interested in. Color matching is an essential procedure to obtain an esthetic prosthesis. Color matching is influenced by several factors, and if not performed properly, it can have unsatisfactory results for both the clinician and the patient. This review discusses color science, factors associated with color perception, and color matching techniques.
\end{abstract}

Keywords: Shade guide; visual color matching; instrumental color matching; color system

$\mathrm{Oz}$

Dental tedavinin başarısı, fonksiyonel ve estetik sonuçlarla değerlendirilir. Protez estetiği, hastanın ilgilendiği en önemli tedavi parametrelerinden biri olarak kabul edilmektedir. Renk seçimi, estetik bir protez elde etmek için gerekli bir prosedürdür. Renk seçimi çeşitli faktörlerden etkilenir, uygun şekilde gerçekleştirilmediğinde ise, hem klinisyen hem de hasta için tatmin edici olmayan sonuçlar doğurabilir. Bu derleme, renk bilimini, renk algısıyla ilişkili faktörleri ve renk seçim tekniklerini irdelemektedir.

Anahtar Kelimeler. Renk skalası; görsel renk seçimi; enstrümantal renk seçimi; renk sistemi

\section{INTRODUCTION}

The esthetic dental result is essential for fulfilling the high expectations of patients. Color and shape determine the esthetics of both restored and natural teeth (1). The importance of color research in dental science has improved significantly over the last decades (2). To provide esthetic prosthesis, the dentist should consider the color's scientific basis as well as the artistic aspects of color matching (3). Because of the great variety of natural teeth color, obtaining a close color match of a prosthesis with the natural teeth is a complex procedure. The dentist needs an understanding of color, light, and characteristics of resin and porcelain in addition to the ability to communicate with the technicians to achieve a natural-looking prosthesis (4). The understanding of the light's nature, how the eye perceives the light, and how the brain interprets light as color is essential for a favorable esthetic prosthesis (5). Color can be described by three primary attributes of color which are hue, chroma, and value. To facilitate communication with the technician, the dentist should be thoroughly familiar with these terms and their definitions (3). Color determination and replication are the greatest challenging parts of dental esthetic (6).

Tooth color is determined using either instrumental or visual methods (7). The most common technique for color matching is the visual method using a shade guide (2). Shade guides have been used to determine and communicate the color of tooth and prosthesis to obtain an optically satisfying prosthesis but misunderstanding could often happen since every human-eye is not capable to perceive it in a standardized way $(8,9)$. Additionally, visual color matching relies on many subjective elements such 
as translucency, surface structure, lighting conditions, and the optical character of the material used (10). Since visual color matching relies on an individual assessment, which is subjective and consequently a clinically challenging procedure. So, this is one of the causes of developing standards for communicating shades and instruments that make it easier to measure them (11). However, instrumental color matching is concerned to be useful and reliable in obtaining color for clinical color matching in dentistry (6). The recommended protocol for visual and instrumental color matching should be followed for a better understanding of the difficulties involved in it (12).

\section{Factors Affecting Color Perception}

Sir Isaac Newton's experiments during the 18th century presented that white light passing through a prism is divided into a pattern of colors termed as spectrum and he proved that color does not exist without light (4). It is the interaction of light with the object that allows the perception of color (13). The perception of the color relies on the combination of three elements, which is a light source, an observer, and an object (14).

\section{Light source}

The light source is the most important element in color matching (1). There are three light sources commonly found in the dental office: natural, incandescent, and fluorescent (3). The natural light is the ideal light source, which occurs around the middle of the day for proper color matching (13). Natural sunlight itself is extremely variable (3). The use of artificial lighting is needed due to the absence of ideal circumstances for color matching (13). Artificial light sources are also lacking in an equal distribution of color. Incandescent light is mainly red-yellow and lacking in blue (3). The color temperature of 5500 Kelvin $\left({ }^{\circ} \mathrm{K}\right)$ is a recommended standard for dental color matching (1). The "color corrected" is special lights that emit light with a more identical distribution of color. Initial color matching should be done using color-corrected lights, but any color matching should be done under more than one type of light to overcome the problem of metamerism (3).

\section{Object}

The objects have no color of their own (5). The object being viewed modifies the light that falls on it by reflecting, absorbing, transmitting, or refracting all or part of the light energy, thereby producing the quality of color (3). A white object reflects all wavelengths of light but a black object absorbs all wavelengths of light. For example, while a blue object absorbs all light wavelengths except blue, which are reflected; by this process, the eye determines the object as blue (15).

\section{Observer}

The eye is an organ that has receptors of images attained from electromagnetic radiation which we name as light. It corresponds to a narrow segment between the 400-800 $\mathrm{nm}$ wavelengths approximately of the entire spectrum (16) (Figure 1). The light reflected from an object can stimulate the cones and rods cells of the retina which enable perception of color (17). The rods cells are responsible for scotopic (monochromatic, low light level) vision while cones cells are responsible for photopic (medium/high light level) vision (14).

\section{Color Systems}

From the beginning of the 20th century to the present, there are many different systems developed to measure colors mathematically (18). Visually descriptive Munsell and the more quantitive CIE color systems are the most emphasized systems in terms of development principles, experiential technique, and qualifications (19).

\section{Munsell Color System}

Prof. Albert D. Munsell presented a color wheel that contains the dimension of Value, Chroma, and Hue at the beginning of the 20th century (20). The color quality that differentiates one color from another is called hue. Hue is the name of a color, e.g. red, orange, or yellow (3). Hue is represented on the Vita Classic shade guide by $A, B, C$, or D. Chroma define as the strength, intensity, or saturation of the hue (21). On the Vita Classic Shade Guide, the higher numbers represent increased chroma (16). Value is the color relative lightness or darkness or the object's brightness (13). According to Munsell, value is described as a black to white grayscale (16) (Figure 2-A). Often the most important dimension of color is the value, as the value decreased, the chroma is increased; value and chroma are inversely related $(1,13)$.

\section{CIE Lab Color System}

The Commission International de l'Eclairage (CIE), in 1931, introduced a system of instrumental color measurement for describing colors (14). One of the first color spaces defined is CIE XYZ. These models are created manually with the help of human judgment ability of appearances and visualization matching, and the chosen colorimetry is based on this matching process. While In 1976, CIELAB color model was introduced, the second uniform color space, was derived from CIE XYZ space, with a white reference point (22). The CIE color system represents a uniform color space, with equal distances corresponding to equal perceived color variances. In this three-dimensional color space, the three-axis are $L * a *$, and $b *$. The $L *$ represents the value which is a lightness measurement of an object and is quantified on a scale as a $100 \mathrm{~L} *$ of value for a perfect black. While the $a *$ value is a quantity of greenness (negative $a^{*}$ ) or redness (positive $a^{*}$ ). Whereas the $b$ * value is a quantity of blueness (negative $b *$ ) or yellowness (positive $b *$ ) (Figure 2-B). The $a *$ and $b$ * coordinates approach zero for natural colors and increase in degree for more intense or saturated colors (16). A more advanced and recent CIE formula, CIEDE2000, has been subsequently presented and it is increasingly used in dentistry for color research (17). CIE Lab system's main advantage is that color variances could be expressed in units that can be related to visual perception and clinical importance (16). 


\section{Color Measurement}

There are two main methods for color matching, the visual method using shade guide, and the instrumental method using color matching devices (23).

\section{Conventional Visual Method}

Visual color matching involves a direct visual comparison of the different color samples in a shade guide with natural teeth in order to determine which tab, or combination of tabs, constitutes the best match (24). The Munsell color system is a common system for visual color assessment. Also, the visual color assessment of the patient's teeth is the most common method applied in dental practice (13). It is economical, commonly available, and it efficiently compares teeth color with a standardized reference shade guide (23). However, the visual method is very subjective, and usually, this method relies on many factors and the observer's psychological and physiologic responses to radiant energy stimulation $(13,25)$. Visual color matching is inconsistent, which may result from uncontrolled factors such as lighting conditions, emotions, aging, fatigue, metamerism, object and illuminant position, and previous eye exposure (13). Visual color matching tools are called shade guides (17). The shade guide's main advantage is that generally they can be used almost anywhere and less expensive (15). The most popular shade guides currently used are:

\section{Vita Classic (Vita Zahnfabrik, Bad Sackingen, Germany)}

It is a very popular shade guide and has been in use since the 1960s (5). VITA classical shade guide contains sixteen tabs. The (A to $D$ ) is the original tab arrangement (Figure 3-A). The four groups are created based on hue: $A$ is reddish-brown ( $A 1, A 2, A 3, A 3.5, A 4), B$ is reddish-yellow (B1, B2, B3, B4), C is gray (C1, C2, C3, C4), and D is reddishgray (D2, D3, D4). Within the groups, tab arrangement is based on decreasing value and increasing chroma. The "value scale" is an alternative tab arrangement which is a gold standard for tooth whitening monitoring. For dental shade matching the "value scale" is more logical and preferred by many over the (A to $D$ ) arrangement (17) (Figure 3-B).

\section{Vitapan 3D-Master (Vita Zahnfabrik, Bad Sackingen, Germany)}

The 3D-Master shade guide was introduced by Vita In the early 1990s, to accurately assess color according to the three components of color: value, chroma, and hue. The 3D-Master attempts a three-dimensional analysis of tooth color, unlike the majority of dental shade guides. The tabs are arranged logically and systematically, rather than randomly as in the Classic guide (5). The 3D-Master have three shade guide type: Linearguide, Bleachedguide, and Toothguide. The VITA Toothguide 3D-Master contains twenty-nine tabs divided into six groups according to lightness. Within the groups, tabs are arranged horizontally according to hue and vertically to chroma (17) (Figure $3-C)$.

\section{Chromascop (Ivoclar - Vivadent, Schaan, Liechtenstein)}

Chromascop is a proprietary shade guide with the same group division principle as VITA classical (17). The Chromascop uses numbers to distinguish hue, for example, for white (100), for yellow (200), for orange (300), for gray (400), for brown (500). Chroma is determined by another set of numbers, 40 are high chroma with low value while 10 are low chroma with high value (5) (Figure 4).

\section{Specific or custom chroma and value guides}

A custom shade tab could be fabricated using porcelain if the teeth color fails to concur with any of the shade guide tabs (5).

\section{Instrumental Method}

The instrumental color matching was presented to the dental practice to reduce the inconsistencies and limitations of the visual color matching method (25). The instrumental methods offer a potential advantage over visual methods which are instrumental measurement is rapidly obtained, can be quantified, and more objective (26). Several studies have proved that computer-aided color analysis is more consistent and more accurate in comparison to the visual method (12). The cost of the instrument is the most significant disadvantage of an instrumental method (23). Visual and instrumental matching methods complement each other and their combined use can lead to more favorable esthetic results (17). All color matching instruments contain a signal conditioner, a detector, and software that processes the signal in a method that produces usable data for dental treatment (27). When using these instruments, the manufacturer guidelines must be followed (25). There are three basic types of devices used for color matching:

\section{Colorimeter}

Colorimeters were the first type of color measuring instrument which approximate the spectral function of the normal vision and are designed to directly measure color as the human eye perceives (14). The colorimeters are instruments for color measurement which are equipped with three or four special filters. The filters obtain RGB (red, green, and blue) values. Colorimeters are usually less accurate than spectrophotometers, but they are often preferred because of their low cost and easily operated (28). ShadeEye (NCC chroma meter) and ShadeVision (X-Rite, Grandville, MI) is an example of a colorimeter (2, 13).

\section{Spectrophotometry}

Spectrophotometry is a device that measures the amount of light energy reflected or transmitted from an object's surface at 1-25 $\mathrm{nm}$ intervals along the visual light spectrum "380-780 nm". For color matching in dental practice, the spectrophotometer can be the most accurate instrument (25). The spectrophotometer contains a source of optical radiation, a detector, a means of dispersing light, a means of converting light obtained to a signal that can be analyzed, and an optical system for measuring 


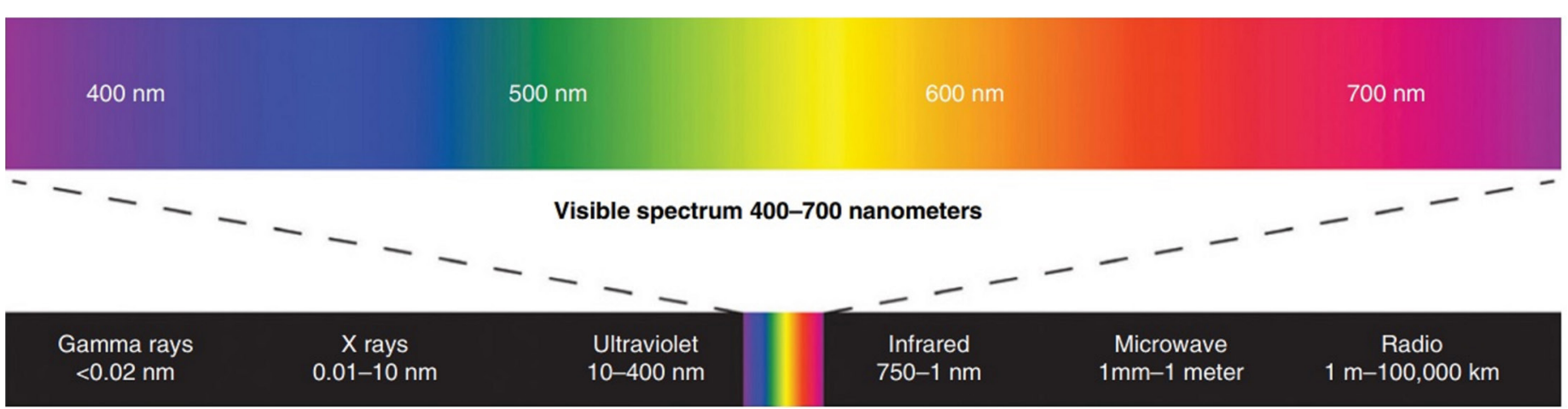

Figure 1. The visible wavelength of light (19).

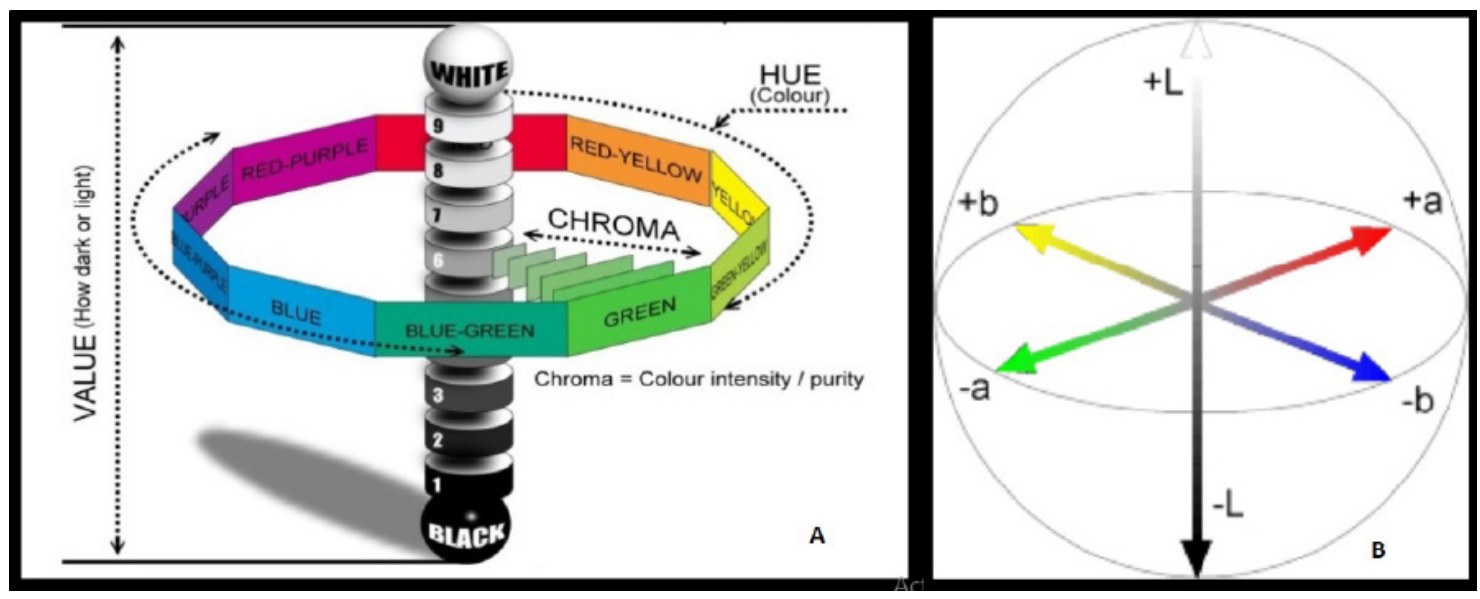

Figure 2. (A) Munsell color system wheel; (B) CIE LAB color system (18).

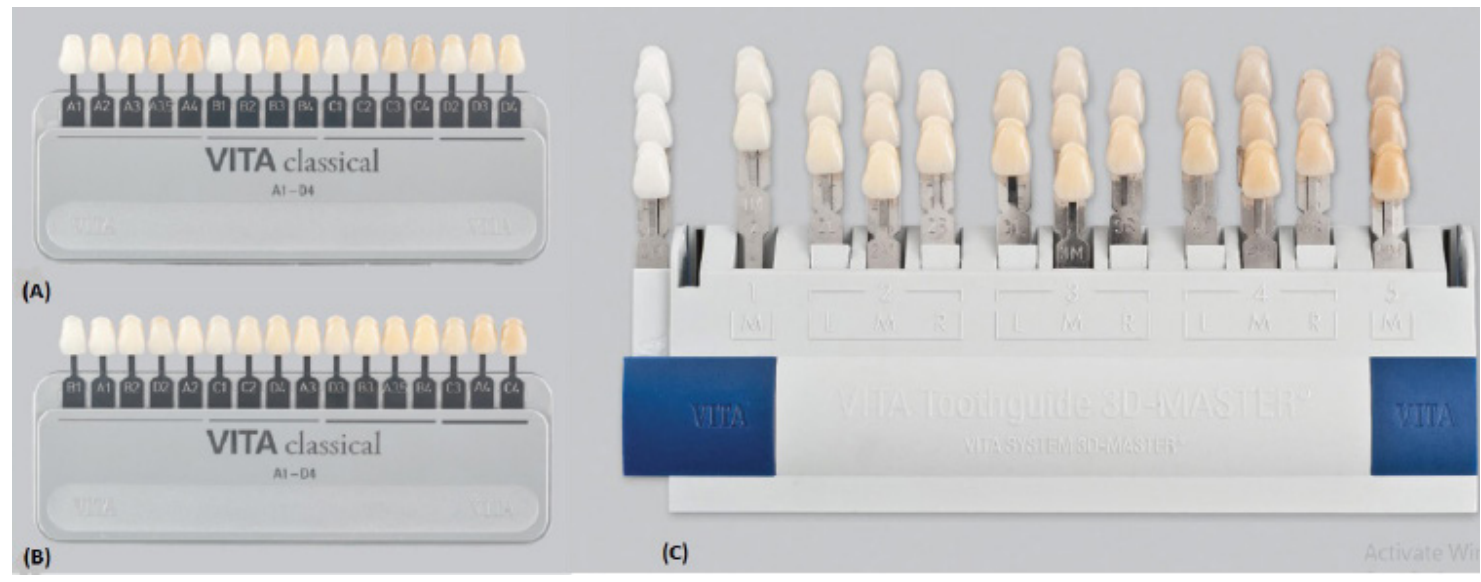

Figure 3. (A) Vita classic A-to-D tab arrangement; (B) value scale; (C) VITA Toothguide 3D-Master (19).

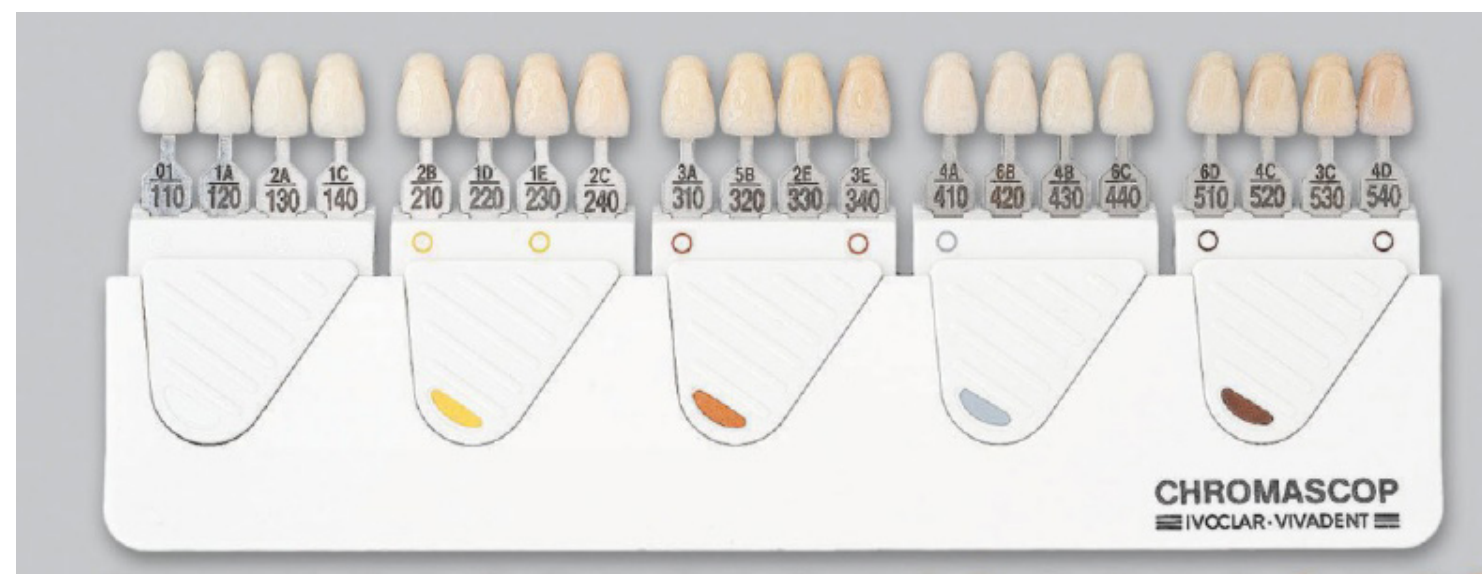

Figure 4. Ivoclar Chromascop guide (19). 
(2). Several intraoral spectrophotometers are currently available (28). Vita Easyshade Compact (Vita Zahnfabrik, Bad Sackingen, Germany) is a color matching cordless device, portable, battery-operated, small, contact-type, and cost-efficient spectrophotometer which provides color measurement is based on the VITAPAN 3D-Master and VITAPAN Classical shades $(2,15)$. SpectroShade (MHT Optic Research, Niederhasli, Switzerland) and Crystaleye (Olympus, Tokyo, Japan) are examples of digital imaging with spectrophotometric analysis $(2,13)$. Reliability percentages are 96.9, for Spectro Shade and 96.4 for VITA Easyshade. The VITA Easyshade accuracy percentages are 92.6 which consider the highest (4).

\section{Digital Camera}

The digital cameras and imaging systems are the third classifications of instrumental color matching devices (25). Digital photography offers significant benefits to dental practices (13). The use of digital cameras in dental practice can be very appealing to the dentist because of their availability, cost, and ease of use (25). Scanners and digital cameras can provide a useful color mapping, used to record color information, and provide a detailed image of the teeth surfaces (17). Images provided through a digital camera can be analyzed using proper software that enables color values collection from parts or whole of those images, however, the digital scanners like those used in (CAD-CAM) systems are also being developed with tooth color matching capability $(25,29)$. ClearMatch (Smart Technology, Hood River, OR) is a software system which uses images with high resolution and compares color over the entire tooth. The system uses three basic color references (white, black, and shade tab) to calibrate and determine the color (28).

\section{Recommended Color Matching Protocols}

- Color matching should be done in different types of lighting conditions. Color matching must be completed between 10 am and $2 \mathrm{pm}$, due to the color temperature is around $5500 \mathrm{~K}$ - which is considered as the best value at this time, after using color corrected light to ensure the accuracy of matched color $(4,13)$.

- Bright colors should be avoided in the working field, brightly colored clothing should be covered and lipstick or other makeup that could affect color matching should be removed (4).

- Tooth to be matched must be cleaned of all stains and debris. Also, the teeth should be cleaned by using prophylaxis paste before color matching.

- The patient has to be viewed at the level of the eye, in such a manner that the most sensitive part of the retina can be used, at a distance of 25 to $35 \mathrm{~cm}(5,24)$.

- Color matching should be done at the beginning of the appointment before the eyes become fatigued and before the preparation of the tooth because the teeth become dehydrated and color changes during preparation $(24,26)$.

- Color matching has to be done quickly, with the color samples positioned under the lip directly next to the tooth being matched, the comparison should not lasting for more than 5 to 7 seconds at a time to avoid fatiguing the cones of the retina. The eye has to be rested by looking on a blue-gray surface immediately before and between a comparison because this will balance all the color sensors of the eye $(3,24,26)$.

- The value must be analyzed first, followed by chroma and hue (4).

- During color matching, the tooth has to be divided into three areas. Incisal area (enamel is the thickest here and varies from translucent to transparent), body, and gingival area (which gives an accurate determination of dentinal chroma) (4).

- Once the best match has been selected, a brighter shade tab and a darker shade tab are photographed next to the teeth to be matched (24).

\section{CONCLUSION}

Patients expect the broken down and missing teeth to be restored with proper form, function, and an esthetic appearance. Color matching forms an important part in producing esthetics prosthesis. The tooth color determination and replication is a challenging task for every dentist. Understanding the science of color, color perception, color matching instrument usage, and limitations, and communication between technicians and dentists are essential for successful esthetics treatments. Accurate color matching that allows the prosthesis to match the natural teeth positively influences the appearance and esthetic self-confidence of the patient.

Financial disclosures: All authors report no financial interests or potential conflicts of interest.

Conflict of Interest: The authors declare that they have no competing interest.

Acknowledgments: The authors declare that there is no conflict of interest associated with this study.

\section{REFERENCES}

1. Afrashtehfar KI. Increased predictability in tooth shadematching. In practice 2013;15:26.

2. Chu SJ, Trushkowsky RD, Paravina RD. Dental color matching instruments and systems. Review of clinical and research aspects. J Dent 2010;38:e2-e16.

3. Shillingburg HT. Esthetic Considerations. In: Shillingburg HT. Fundamentals of fixed prosthodontics. 4th edition. USA: Quintessence Publishing Co; 2012. p. 413-24.

4. Basavanna R, Gohil C, Shivanna V. Shade selection. Int J Oral Health Sci 2013;3:26.

5. Shammas M, Alla RK. Color and shade matching in dentistry. Trends Biomater Artif Organs 2011;25:172-5.

6. Chang $\mathrm{J}-\mathrm{Y}$, Chen $\mathrm{W}-\mathrm{C}$, Huang $\mathrm{T}-\mathrm{K}$, et al. Evaluating the accuracy of tooth color measurement by combining the Munsell color system and dental colorimeter. Kaohsiung $\mathrm{J}$ Med Sci 2012;28:490-4. 
7. Nakhaei M, Ghanbarzadeh J, Amirinejad S, et al. The influence of dental shade guides and experience on the accuracy of shade matching. Contemp Dent Pract 2016;17:22-6.

8. Lee Y-K, Yu B, Lim JI, Lim HN. Perceived color shift of a shade guide according to the change of illuminant. $J$ Prosthet Dent. 2011;105(2):91-9.

9. Ishikawa-Nagai S, Sato RR, Shiraishi A, K Ishibashi. Using a computer color-matching system in color reproduction of porcelain restorations. Part 3: A newly developed spectrophotometer designed for clinical application. Int $\mathrm{J}$ Prosthodont 1994; 7: 50-5.

10. Lehmann KM, Devigus A, Igiel C, et al. Repeatability of colormeasuring devices. Eur J Esthet Dent 2011;6:428-35.

11. Yap A, Sim C, Loh W, J H Teo. Human-eye versus computerized color matching. Oper Dent 1999;24(6):358.

12. Bhat V, Prasad DK, Sood S, Bhat A. Role of colors in prosthodontics: Application of color science in restorative dentistry. Indian J Dent Res 2011;22(6):804.

13. Agrawal VS, Kapoor S. Color and shade management in esthetic dentistry. Universal Res J Dent 2013;3:120-7.

14. Burkinshaw SM. Colour in relation to dentistry. Fundamentals of colour science. Br Dent J 2004;196:33-41.

15. Goldstep F, Freedman G. Color and Shade. In: Freedman G. Contemporary Esthetic Dentistry. 1st edition. UK:Elsevier Mosby; 2012. p. 135-67.

16. Vadher R, Parmar G, Kanodia S. Basics of color in dentistry: A review. J Dent Med Sci 2014;13:78-85.

17. Paravina RD. Understanding Color. In: Goldstein RE, Lee EA, Stappert CFJ. Esthetics in Dentistry. 3rd edition. USA: John Wiley \& Sons Inc; 2018. p. 272-94.

18. Billmeyer FW, Saltzman M. Principles of color technology. Color and Color Difference Measurement, 2nd edition. New York: Wiley; 1981. p. 67-109.
19. Wee AG. Description of Color, Color-Replication Process, and Esthetics. In: Rosenstiel SF, Land MF, Fujimoto J. Contemporary Fixed Prosthodontics. 5th edition. Missouri: Elsevier Inc; 2016. p. 624-46.

20. Chu SJ, Devigus A, Rade P, et al. Color Theory. In: Chu SJ, Devigus A, Rade P, Mieleszko AJ. Fundamentals of color, shade matching and communication in esthetic dentistry. 2nd edition. Chicago: Quintessence Publishing Co, Inc; 2010. p. 7-18.

21. Boksman LJOD. Shade Selection: Accuracy and Reproducibility. Ontario Dentist. 2007;84:24-7.

22. Ibraheem NA, Hasan MM, Khan RZ, et al. Understanding color models: a review. J Sci Technol 2012;2:265-75.

23. Borse $\mathrm{S}$, Chaware $\mathrm{SH}$. Tooth shade analysis and selection in prosthodontics: A systematic review and meta-analysis. J Indian Prosthodont Soc 2020;20:131.

24. Chu SJ, Devigus $A$, Rade $P$, et al. Conventional Shade Matching.In: Chu SJ, Devigus A, Rade P, et al. Fundamentals of color, shade matching and communication in esthetic dentistry. 2nd edition. Chicago: Quintessence Publishing Co, Inc; 2010. p. 41-56.

25. Ragain JC. A review of color science in dentistry: shade matching in the contemporary dental practice. J Dent Health Oral Disord Ther 2016;4:1-5.

26. Sikri VK. Color: Implications in dentistry. J Conserv Dent 2010;13:249.

27. Smitha A, Savitha P. Shade matching in aesthetic dentistryfrom past to recent advances. J Dentistry Oral Care Med 2017;3:102.

28. Ivan R. Rade P. Color Measuring Instruments. Acta Stomatol Naissi 2009;25:925-32.

29. Jarad FD, Russell MD, Moss BW. The use of digital imaging for colour matching and communication in restorative dentistry. Br Dent J. 2005;199(1):43-9. 